Grażyna KARP, Wojciech DZIĘGIELEWSKI

Air Force Institute of Technology (Instytut Techniczny Wojsk Lotniczych)

\title{
THE USE OF INSTRUMENTAL METHODS TO IDENTIFY LIQUID FUELS APPLIED IN THE POLISH ARMED FORCES
}

\author{
Wykorzystanie metod instrumentalnych do identyfikacji \\ paliw ciekłych wykorzystywanych w Silach Zbrojnych RP
}

\begin{abstract}
The publication topic is to present the research results on the identification methodology of liquid fuels used in the Polish Armed Forces and beyond them. The part related to the use of non-standard instrumental methods to recognise the differences between various types of products was presented. The results of testing the samples of diesel fuels and fuels for aircraft turbine engines both from the civil market and from the stock of the armed forces were described. The usefulness of chromatography, infrared (IR) spectrometry and UV-VIS spectroscopy as instruments being an element of the procedure of the fuel type and origin identification was presented.
\end{abstract}

Keywords: aviation fuel, diesel fuel, spectroscopy, chromatography, laboratory tests

Streszczenie: Tematem publikacji jest prezentacja wyników badań nad metodyka identyfikacji paliw ciektych wykorzystywanych $w$ Siłach Zbrojnych RP i poza nimi. Przedstawiono część zwiazana z wykorzystaniem niestandardowych metod instrumentalnych do rozpoznawania różnic między różnymi rodzajami produktów. Opisano wyniki badań próbek olejów napędowych oraz paliw do turbinowych silników lotniczych, pochodzacych zarówno z rynku cywilnego, jak i z zapasów sit zbrojnych. Zaprezentowano przydatność chromatografii, spektrometrii w podczerwieni (IR) i spektroskopii UV-VIS, jako instrumentów będacych elementem procedury identyfikowania rodzaju i pochodzenia paliwa.

Słowa kluczowe: paliwo lotnicze, olej napędowy, spektroskopia, chromatografia, badania laboratoryjne 


\section{Introduction}

In recent years, a great number of proceedings, conducted by military law enforcement authorities, related to the suspected theft of fuels from units subordinated the Minister of National Defence have been observed.

In the process of investigation procedure and evidentiary proceedings, it is necessary to identify the potential source of fuel or the mixture component. The quality of liquid fuels is most often tested for compliance with the requirements included in the official documents applicable on the market - Polish standards on fuels, for example: PN-EN 590 for diesel fuels [5], AFQRJOS for aviation fuel) [1] and Regulations of the Minister of Economy on the quality of fuels and biofuels [6]. Another issue includes the fuel tests for the Polish Armed Forces. In this case, the normative documents like Defence Standard NO-91-A219 for the F-54 type diesel [2], or NO-91-A258-2 for the F-34 type aviation fuel [3] are applicable.

The fuels used in the Polish Armed Forces differ from "civil" fuels in terms of the composition and some parameters, e.g. "military" diesel fuel should not contain fatty acid methyl esters (FAME) and it should be characterised by a low cold filter plugging point (CFPP) regardless of the season. However, this parameter does not uniquely identify the "military" fuel because the civil oil of the Arctic type also has such a requirement, and fuel with a significantly reduced value of the CFPP parameter can be widely available, when the ambient temperature decreases below $-20^{\circ} \mathrm{C} \div-25^{\circ} \mathrm{C}$. The automotive fuel used in the Armed Forces may be the same as the one coming from commercial petrol stations. The only parameter that could be possibly taken into account when trying to identify the fuel origin is alcohol content. In accordance with the quality clauses according to which the fuel for the needs of the Armed Forces is purchased, the alcohol content cannot be higher than $0.1 \%(V / V)$. Such petrol is rather not met at commercial stations, though such a situation cannot be excluded. It is easier to identify the aviation fuel intended for the army, in which an anticorrosive and lubricating additive was introduced at the production stage. In addition, during the fuel preparation for the military aircraft refuelling, an additive that prevents water crystallisation is added to it. In this case, these are obvious characteristics of the product, which is not used in the civil area.

Owing to the substantial similarity of fuels in terms of their type, production place, intended use and basic properties, the limitation to the assessment of normative parameters is not sufficient. Experience shows that sometimes, in spite of obvious differences, the similarity is high enough that with the use of standard tests it is not possible to clearly differentiate between "civil" fuels and fuels "intended for military purpose". 
Therefore, there is a justified need to develop procedures intended for a deeper analysis of evidence. These activities will also make it possible to reduce costs associated with the necessity of managing a wide range of normative tests, the final result of which is not always useful in order to achieve the intended objective, i.e. to detect or exclude the presence of the fuel used in the Polish Armed Forces in the tested samples of evidence.

In addition to the testing methods detailed in the specifications of operating liquids, including fuels, the so-called non-standard methods, which include instrumental methods based on highly specialised analytical techniques and data modelling with the use of chemometric tools, are applicable. Their use in the complex experimental data analysis facilitates, among others, their interpretation and exploration, thus resulting in more and more extensive use of various chemometric approaches, e.g. to the analysis of chromatographic "fingerprints" in the context of individual control of characteristics of the selected products. The signals obtained for complex samples and describing the chemical components contained in them have a large resource of information about the tested sample. The analysis of this data type is most often based on a comparison of the obtained instrumental signals between them or in relation to signals obtained for reference samples. Each sample is described by an analytic signal reflecting the chemical information included in the sample. The complexity of analytic signals results from the aggregation of information from each component of the sample. Unlike the standard tests, the sample analysis does not involve the performance of activities aimed at testing the selected product parameters and possible confirmation of their compliance with the strictly determined requirements. First and foremost, the difficulty is the lack of clearly and formally defined assessment criteria, as well as the standardised research methodology. Therefore, a very useful supporting instrument is the database, which - if properly developed - can be statistically used for qualitative and quantitative assessment. On this basis, it is possible to determine the typical composition of individual types and grades of fuels, and then, refer the tested sample composition to it. Owing to the considerable variety of a range of fuels both in the armed forces and beyond them, there is a necessity to create a suitably numerical database and an appropriately extensive statistical material.

There are several non-standard methods, with the use of which it is possible to make an attempt to select the characteristics for fuels with various origin and purpose (in the context of operation in the conditions specific for the armed forces vs. in the civil conditions). Therefore, it is possible to use, e.g. gas chromatography, liquid chromatography, infrared spectroscopy, fluorescence spectroscopy, or UVVIS spectroscopy. When choosing a method for practical use, its availability, complexity level or testing cost do not remain unimportant. These factors 
significantly direct the work on the identification methodology of liquid fuels used in the armed forces.

\section{The use of non-standard instrumental methods to identify the liquid fuels}

It was assumed that the identification test methodology of liquid fuels with special emphasis on "military" fuels will be based on the multi-parametric assessment of properties of the tested facilities, using both standard and nonstandard tests of properties and chemical composition of fuels. This study shows only a part including non-standards tests.

The identification of individual types of fuels is based on the assumption that it is possible to demonstrate the obvious composition differences with the appropriately selected methods. The additional problem that greatly complicates the identification process is the prevalence of mixtures of different fuels, and quite often also the components that are not fuels, but which can be subjected to combustion in the engines. For this reason, the database was expanded with the test results of mixtures of different fuels (prepared in laboratory). The base is open, and it can be supplemented with subsequent test results of next fuels or mixtures, and then, on this basis, the assessment criteria can be verified.

In the early stage of the database creation, the Jet A-1 aviation (civil) fuel samples, the F-34 aviation fuel samples (used in the Polish Armed Forces), as well as the samples of diesel fuels purchased at civil petrol stations that belong to various distributors, and the samples of the F-54 diesel fuel applied in the Polish Armed Forces, were obtained. The diesel fuel (diesel) and aviation fuel (Jet) samples were used in order to prepare mixtures with the following proportions: $25 \%(V / V) \mathrm{Jet}+$ $75 \%(V / V)$ diesel, 50\% (V/V) Jet $+50 \%(V / V)$ diesel, 75\% $(V / V)$ Jet $+25 \%(V / V)$ diesel.

The samples of fuels and their mixtures were tested in a selected range for the compliance with the NO-91-A219 [2], NO-91-A258-2 [3] and NO-91-A258-4 [4] standards. In addition, the non-standard tests, the results of which were presented below, were performed.

It was presented in fig. 1 which shows chromatograms of two different fuels layered upon each other. A difference is visible in the chemical composition of the fuel typical for the Jest A-1 aviation turbine engines and diesel fuel (Diesel). The difficulty in distinguishing between aviation fuel and diesel fuel on the basis of the chromatographic test results is a common range of retention times, which completely includes a range of the occurrence of aviation fuel components. 


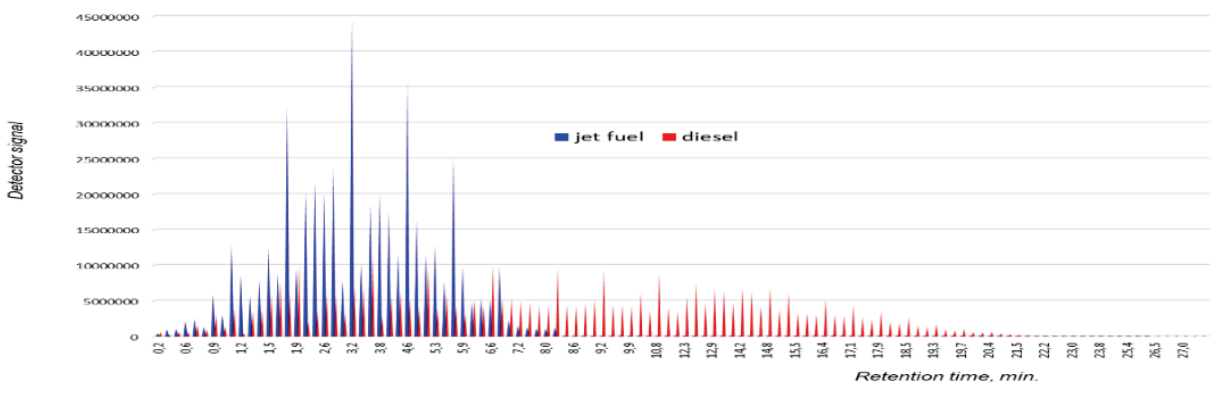

Fig. 1. Chromatogram for aviation fuel and diesel fuel [7]

Although the signal intensity (peak height) is higher, but it still reduces the method selectivity, especially when a mixture of different fuels is analysed. Then, the aggregated peaks for all components of the mixture are then visible in the chromatogram.

a)

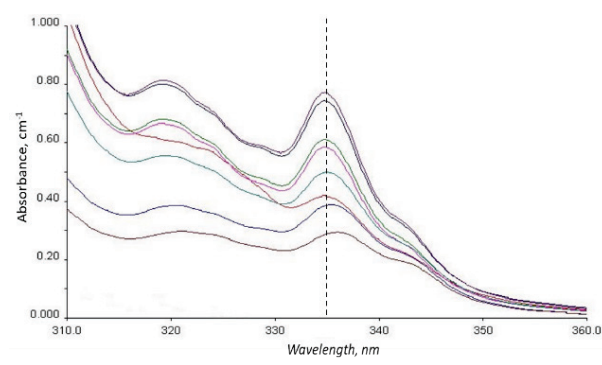

c)

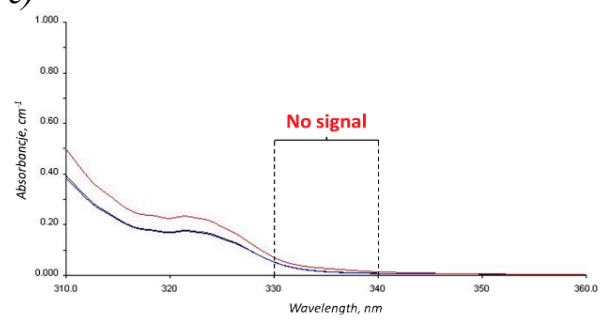

b)

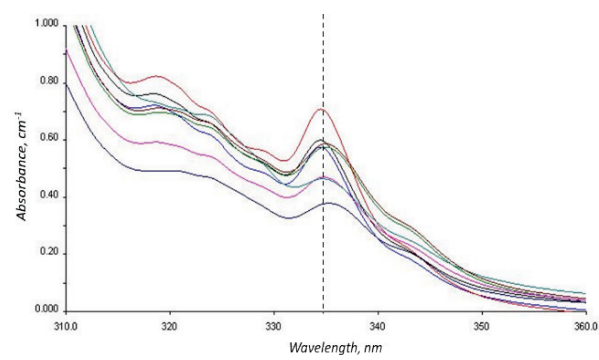

d)

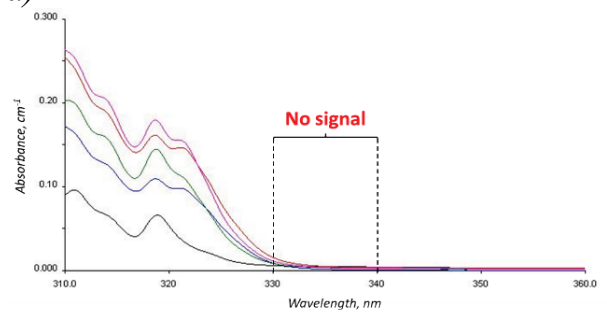

Fig. 2. UV-VIS spectra of samples: a): civil diesel fuels from $2016 \mathrm{r}, \mathrm{b}$ ) civil diesel fuels from 2017 r, c) F-54 diesel fuels, d) Jet A-1 and F-34 type fuels for aircraft turbine engines [7] 
Much better selectivity was obtained as a result of tests with the use of the UVVIS spectroscopy. It was observed that there is a wavelength range, in which there is a clear peak for "civil" diesel fuels (peak in the area of $330-340 \mathrm{~nm}$ with maximum absorption for the wavelength $\lambda \approx 335 \mathrm{~nm}$ ), and at the same time, there is a lack of it during testing the F-54 fuel and aviation fuels,

Therefore, it is a useful tool to eliminate the presence of fuel from publicly available sources in the mixture. The example test results of the UV-VIS spectra have been presented in fig. 2. The samples from several production batches (produced by different manufacturers and in different years) were used. The accidental achievement of such results is unlikely - no peak in the area of 330 $340 \mathrm{~nm}$.

Moreover, it was checked whether the peak is derived from the biocomponent (fatty acid methyl esters - FAME), which is introduced to the "civil" diesel fuels, and it should not be present in any fuel intended for the armed forces. Fig. 3 shows the results of testing the sample of the F-54 diesel fuel, to which a typical amount of the biocomponents was inserted. There was no change in the spectrum course in the range of $330-340 \mathrm{~nm}$, which shows that the differences in the fuel spectra do not come from FAME.

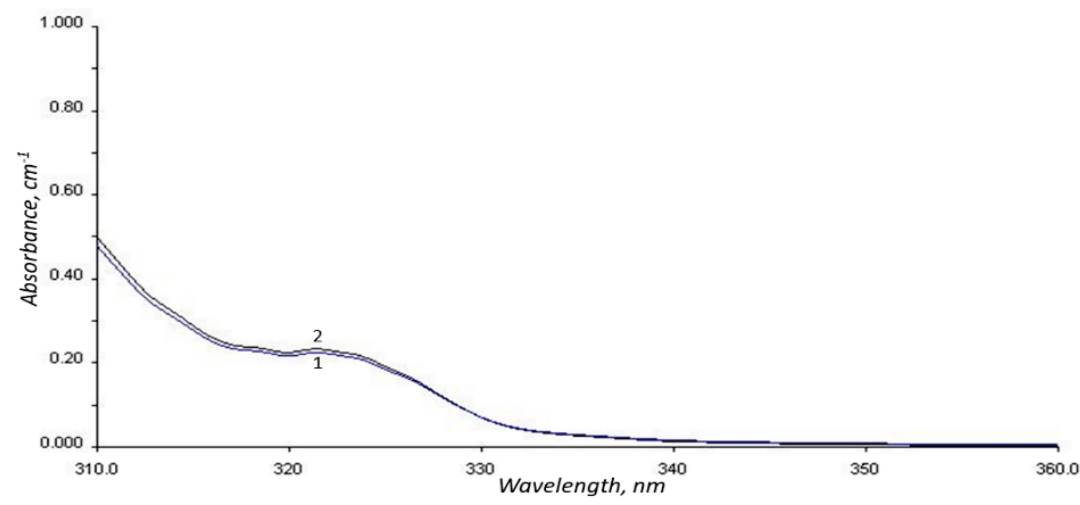

Fig. 3. UV-VIS spectra of the F-54 (1) and F-54 fuels + 5\% (V/V) FAME (2) [7]

By testing the mixtures of two fuels, which show different features within the assumed spectrum range, no interaction was found as a result of mixing fuels (fig. 4) - the linearity of changes was practically obtained. Therefore, it is possible to approximately assess the share of the mixture components. In practice, the accuracy of such estimates is small, which results from the fact that the features of the mixture components are most often unknown before mixing. However, if one 
of the components is known, the accuracy of determining the percentage composition is quite high.

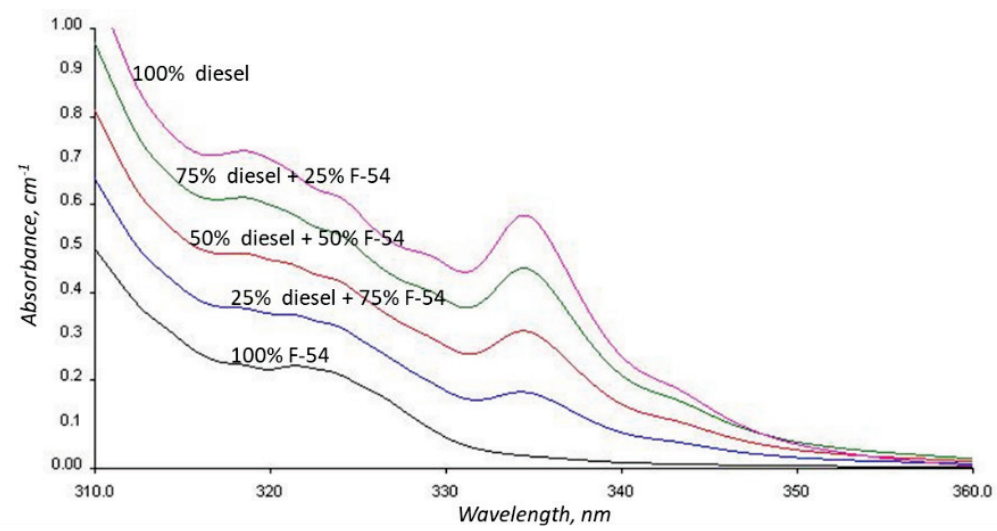

Fig. 4. Overview of UV spectra in the range of $310-360 \mathrm{~nm}$ of the F-54 diesel fuel and "civil" diesel fuel mixtures [7]

In order to identify fuels, the infrared (IR) spectroscopy method was also used. This method is useful for identifying characteristic fragments of molecules, like carbonyl group, an aromatic ring etc. It allows to analyse the structure of molecules. Unfortunately, this method is not useful for identification of mixtures with a high similarity. By using it, it is possible to distinguish between the aviation fuel and diesel fuel. Regardless of the application, the diesel fuels show an additional peak in the IR spectrum (for the wavenumber of approx. $1636 \mathrm{~cm}^{-1}$ ) that the aviation fuels do not have (fig. 5). However, it is impossible to distinguish between the F-54 diesel fuel and the "civil" diesel fuel or the F-34 aviation fuel and the Jet A-1 one (fig. 6).

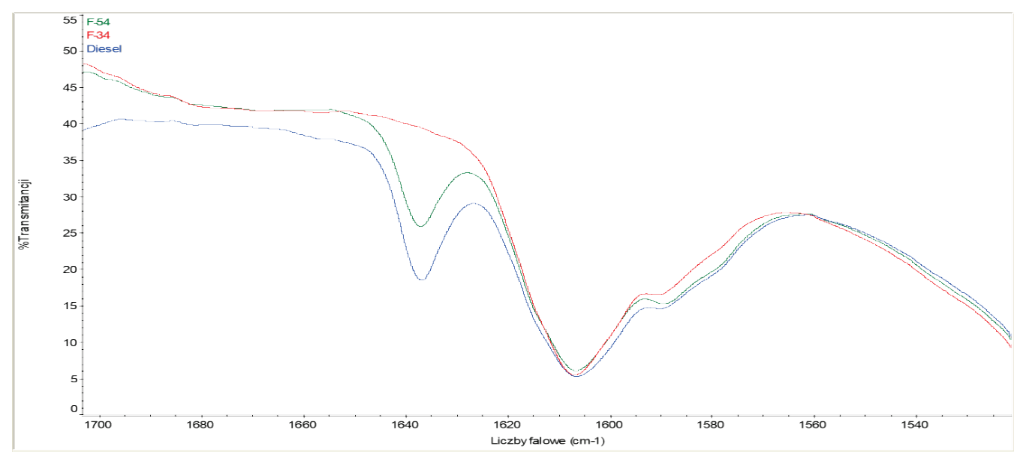

Fig. 5. Example IR spectra of the F-34 type fuel, F-54 fuel and "civil" diesel fuel [7] 
a)

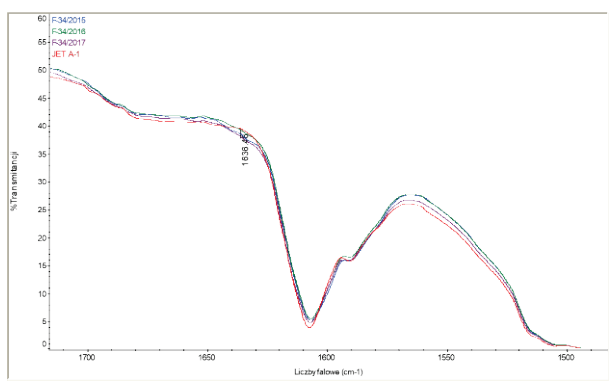

b)

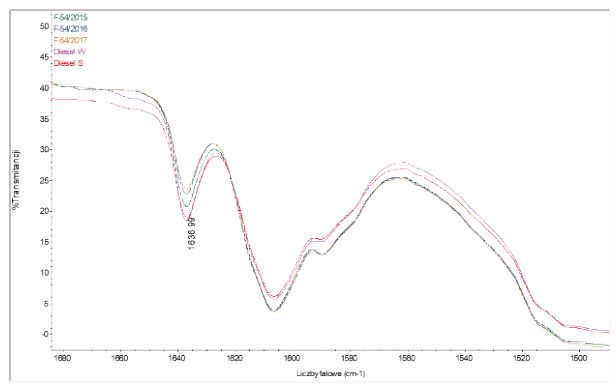

Fig. 6. Example IR spectra of aviation fuels (a) and diesel fuels (b) [7]

\section{Conclusion}

The area of liquid fuels is quite clearly specified, and every type and grade of fuel has strictly defined specifications including a set of properties and requirements that should be met, so that the fuel can be safely operated. Each fuel has individual features, on the basis of which it is assessed in terms of suitability for use in accordance with its intended purpose. Despite this fact, in the majority of cases related to the need to identify the fuel and their mixtures, the standard methods occurred to be insufficient. It is especially difficult when the mixtures with unspecified composition are analysed.

The procedure for identifying fuels with a very similar chemical structure, which were composed of fractions that very often come from the same crude oil processes is a major technical problem. Most of the commonly used methods identifies the differences to a limited extent. Therefore, at the same time, it is necessary to use the multi-parametric assessment, in which the final evaluation constitutes a resultant of effects - assessment of individual partial results. As input data, the results of the selected standard tests and tests implemented with the use of highly specialised analytical techniques based on spectroscopy and chromatography are useful.

The above presented work results were applied to develop a methodology of conduct when analysing the evidence in the proceedings related to the fuel thefts. In addition to the assessment of the selected standard parameters, they constitute a useful element in the process of identifying the fuels and their mixtures.

The article uses the performance results of the research topic implemented within the framework of resources from the Ministry of Science and Higher Education for statutory activities in 2016/2017. 


\section{References}

1. AFQRJOS Eds. 28 - April 2015 Wymagania jakości paliwa lotniczego dla użytkowanych wspólnie systemów [Aviation fuel quality requirements for jointly used systems]

2. NO-91-A219:2007/A1:2009 Materiały pędne i smary - Olej napędowy kod NATO F-54 [Petroleum, oil and lubricants - Diesel fuel NATO Code F-54]

3. NO-91-A258-2:2011 Materiały pędne i smary - Paliwo do turbinowych silników lotniczych - Część 2: Paliwo kod NATO F-34 [Petroleum, oil and lubricants - Fuel for aircraft turbine engines - Part 2: Fuel NATO Code F-34]

4. NO-91-A258-4:2006/A1:2012 Materiały pędne i smary - Paliwo do turbinowych silników lotniczych - Paliwo kod NATO F-35 [Petroleum, oil and lubricants - Fuel for aircraft turbine engines - Fuel NATO Code F-35]

5. PN-EN 590+A1:2011 Paliwa do pojazdów samochodowych - Oleje napędowe Wymagania i metody badań [Fuels for automotive vehicles - Diesel fuels - Research requirements and methods]

6. Rozporządzenie Ministra Gospodarki w sprawie wymagań jakościowych dla paliw ciekłych z dnia 9 października 2015 r. [Regulation of the Minister of Economy on quality requirements for liquid fuels of 9 October 2015].

7. Sprawozdanie $\mathrm{nr} 1 / 55 / 2018$ Opracowanie metodyki identyfikacji paliw ciekłych wykorzystywanych w Siłach Zbrojnych RP [Report no. 1/55/2018 Development of the methodology for identification of liquid fuels used in the Polish Armed Forces] 